\title{
The Taxonomic Designation of Eriogonum corymbosum var. nilesii (Polygonaceae) is Supported by AFLP and cpDNA Analyses
}

\author{
Mark W. Ellis, ${ }^{1,3}$ Jessie M. Roper, ${ }^{1}$ Rochelle Gainer, ${ }^{1}$ Joshua P. Der, ${ }^{1}$ and Paul G. Wolf ${ }^{2}$ \\ ${ }^{1}$ Department of Biology, Utah State University, Logan, Utah 84322 U. S. A. \\ ${ }^{2}$ Ecology Center and Department of Biology, Utah State University, Logan, Utah 84322 U. S. A. \\ ${ }^{3}$ Author for correspondence (e-mail: mwe.sci@gmail.com)
}

\section{Communicating Editor: Daniel Potter}

\begin{abstract}
We examined populations of perennial, shrubby buckwheats in the Eriogonum corymbosum complex and related Eriogonum species in the subgenus Eucycla, to assess genetic affiliations of the recently named E. corymbosum var. nilesii. The known populations of this variety are all located in Clark County, Nevada, U. S. A. We compared AFLP profiles and chloroplast DNA sequences of plants sampled from populations of E. corymbosum var. nilesii with those of plants representing other E. corymbosum varieties and related Eriogonum species from Colorado, Utah, northern Arizona, and northern New Mexico. We found evidence of genetic cohesion among the Clark County populations as well as their genetic divergence from populations of other E. corymbosum varieties and species. The genetic component uncovered in this study supports the morphological findings upon which the nomenclatural change was based, attesting to the taxonomic distinctness of this biological entity.
\end{abstract}

Keywords—buckwheat, chloroplast sequences, Colorado Plateau, Mojave, principal components analysis, Structure 2.2.

Polygonaceae is a large and diverse angiosperm family comprising 48 known genera with approximately 1,200 recognized species (Freeman and Reveal 2005). Several studies have demonstrated the monophyly of the family (Chase et al. 1993; Cuenoud et al. 2002; Lamb-Frye and Kron 2003; Sanchez and Kron 2008) but sorting out taxonomic relationships within Polygonaceae has been a long-standing challenge. It has been suggested that these difficulties, particularly in the subfamily Eriogonoideae, may be due to relatively recent and rapid diversification (Welsh et al. 2003; Sanchez and Kron 2008).

Polygonaceae has been variously subdivided based on morphological characters into subfamilies in numerous circumscriptions (e.g. Arnott 1832; Luerssen 1882; Roberty and Vautier 1964; Reveal 1978, 1989; Freeman and Reveal 2005). Molecular studies (Chase et al. 1993; Lledo et al. 1998; Cuenoud et al. 2002) failed to support the earlier classifications. More recently, Lamb-Frye and Kron (2003) analyzed Polygonaceae with chloroplast $r b c L$ sequences and Sanchez and Kron (2008) included additional cpDNA sequences along with portions of the nuclear gene LEAFY. Findings of both studies supported monophyly of Polygonaceae and its subdivision into two redefined clades-Polygonoideae and Eriogonoideae.

Eriogonoideae sensu Sanchez and Kron (2008) includes several examples of endemism in the geographic region of the southwestern United States (Archibald et al. 2001; Meyer 1986; Reveal 2004b; Welsh 1978). This area appears to comprise a zone of adaptive radiation, with endemics from other plant families found there as well (Douglas and Manos 2007; Meyer 1986; Nickrent and Wiens 1989; Sivinski and Knight 1996). The narrow ranges for some endemic taxa may point to recent diversification in this arid region of North America (Reveal 1989, 2005; Sanchez and Kron 2008). Edaphic factors, including gypsum-rich soils, may play a role in plant diversification and endemism in North America's southwestern deserts (Douglas and Manos 2007; Drohan et al. 2006; Maschinski et al. 2004; Moore and Jansen 2007). Glacial and postglacial climate change may also have contributed to taxonomic divergence through range contraction and expansion, fragmentation, and hybridization of taxa (Comes and Kadereit 1998; Fehlberg and Ranker 2009). This putative history of recent divergence may explain past difficulties in determining relationships within Eriogonoideae.
The Eriogonum corymbosum Benth. complex (Eriogonoideae), as currently recognized, comprises a group of buckwheat taxa distributed across the western U. S. A., from southwestern Wyoming, through Utah and southwestern Colorado, to northern Arizona, northern New Mexico, and southern Nevada (Reveal 2005). Across the range, these woody shrubs vary in size, leaf shape and surface structure, predominant flower color, and overall habit, among other aspects of morphology. A putative history of dispersion, isolation, divergence, hybridization, and introgression may have contributed to the group's morphological and geographical diversity (Reveal 2002; Welsh et al. 2003). The group has been revised on several occasions (Jones 1903; Reveal 1967, 2002, 2005), with eight varieties currently recognized.

Until recently, predominantly yellow-flowered populations of E. corymbosum in Clark County, Nevada, have been treated either as the wide ranging E. corymbosum var. glutinosum (Reveal 2002) or the more narrowly distributed E. corymbosum var. aureum (Reveal 1983, 1985). Identification of E. corymbosum var. glutinosum had previously hinged primarily on flower color (with predominantly yellow-flowered plants identified as variety glutinosum). However, Reveal (2002) pointed out that flower color in the predominantly yellow-flowered Eriogonum Michx. taxa can vary among individuals within populations, which often include white or cream-colored members. In our field observations we also found this to be the case. Although yellow flower color is useful, in combination with other traits, for identifying subspecific taxa within Eriogonum, flower color alone is not definitive for any variety.

The only known population of E. corymbosum var. aureum is located north of St. George, Utah (Appendix 1; Figs. 1, 2), a predominantly yellow-flowered variety distinguishable from variety glutinosum based on glabrous branches of the inflorescence (Reveal 2005). This trait also separates variety aureum from the predominantly yellow-flowered plants in the E. corymbosum populations of Clark County, Nevada, whose flowering branches tend to be silvery-pubescent. Both sides of the leaves of the Clark County plants are silvery-pubescent, separating them from varieties glutinosum and aureum. Based on these traits, as well as ecological considerations, Reveal (2004a) concluded that the Clark County populations are 


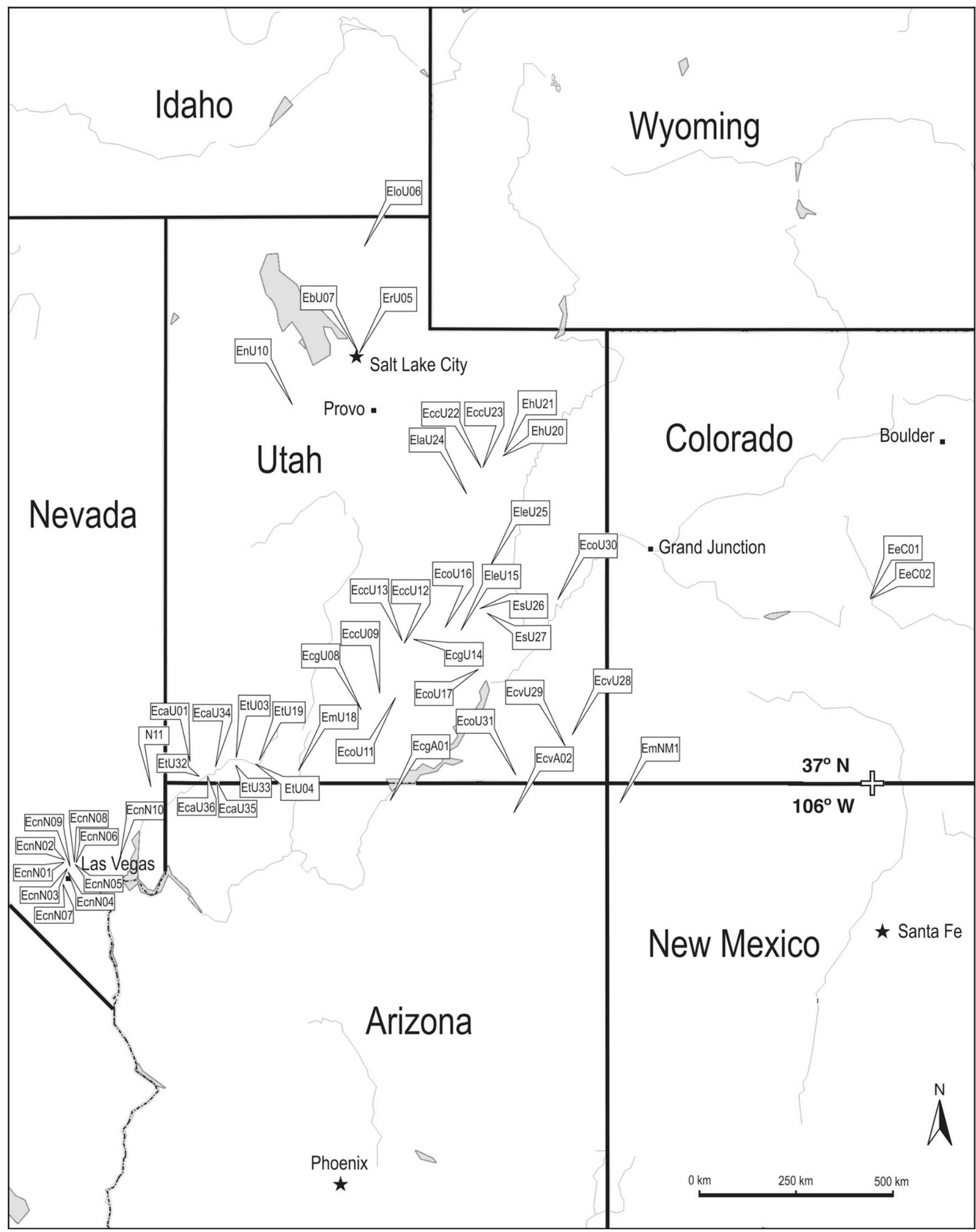

FIg. 1. Collection sites (11 in Nevada, two in Arizona, one in New Mexico, 35 in Utah). See Table 1 for key to abbreviations. 


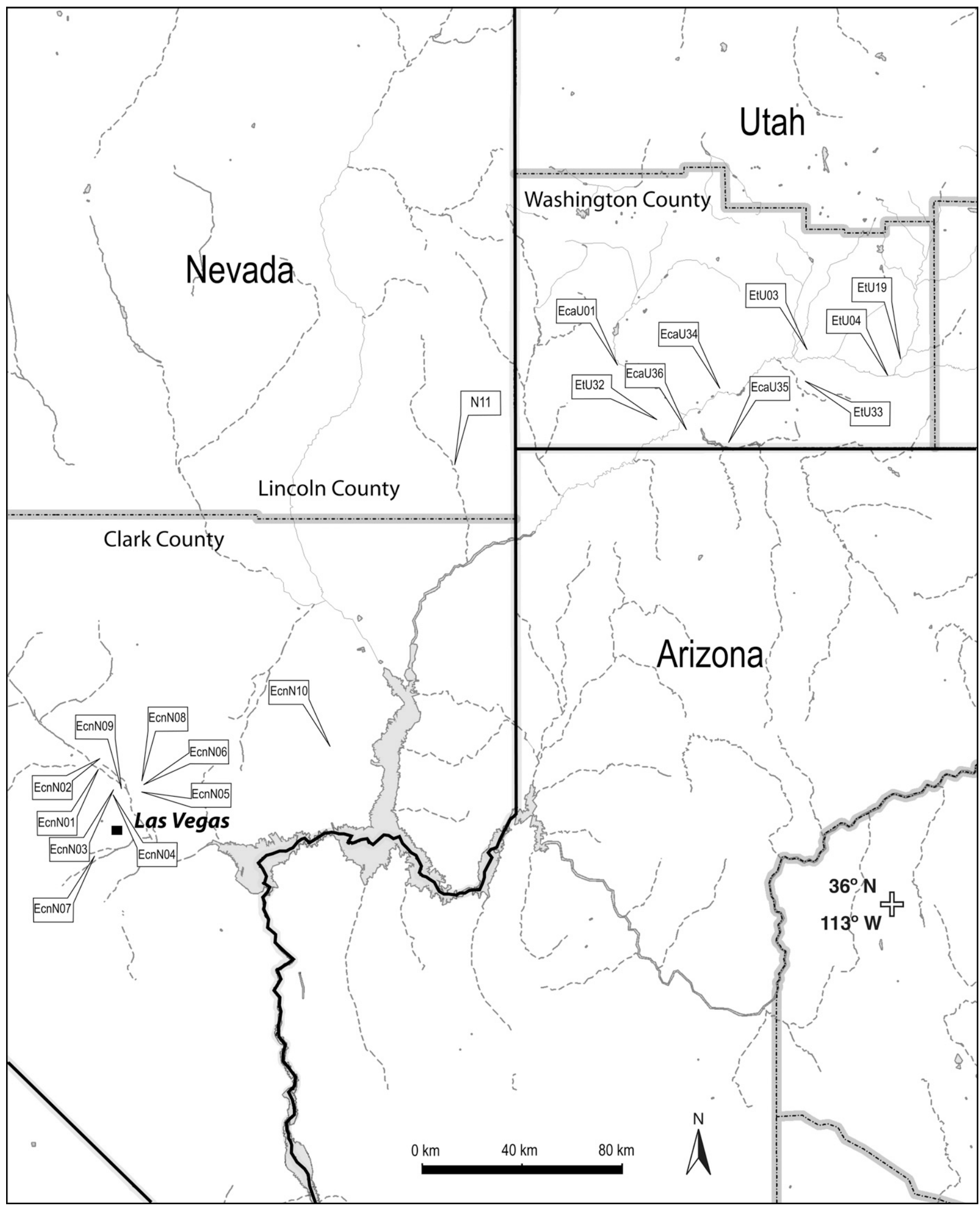

Fig. 2. Sites sampled in Clark County, Nevada (E. corymbosum var. nilesii), Lincoln County, Nevada (E. corymbosum N11), and Washington County, Utah (E. corymbosum var. aureum and E. thompsoniae). 
morphologically and ecologically distinct and geographically disjunct from both E. corymbosum varieties glutinosum and aureum, and he proposed the new varietal designation nilesii (Niles's wild buckwheat). The known populations of E. corymbosum var. nilesii are mainly in and around Las Vegas and the Muddy Mountains region of Clark County, Nevada (Reveal 2005).

Concerns have been expressed regarding the loss of the Clark County populations of E. corymbosum var. nilesii as a result of development and off-road vehicle recreation, and questions about its taxonomic status have been raised (Reveal 2004a). Eriogonum corymbosum var. nilesii is currently listed by the Bureau of Land Management (BLM) as a sensitive species (Boettinger et al. 2007) and the U.S. Fish and Wildlife Service (USFWS) recently selected it as a candidate for protection under the Endangered Species Act of 1973 (ESA) (USFWS 1983; Perkins and Samargo 2008). Further evidence demonstrating the taxonomic distinctness of E. corymbosum var. nilesii would lend support to an ESA listing, whereas evidence to the contrary might suggest that the Clark County populations are part of a more widespread taxon.

Here we examine populations in the E. corymbosum complex and related Eriogonum species in subgenus Eucycla to address the genetic distinctness of the populations of E. corymbosum var. nilesii found in Clark County, Nevada. By analyzing a combination of amplified fragment length polymorphism (AFLP) and chloroplast DNA (cpDNA) data, we evaluate the conclusion of Reveal (2004a) that the Clark County populations of E. corymbosum have diverged in a manner and to an extent that warrants this varietal recognition.

\section{Materials AND Methods}

Collections-Based on recorded locations from herbarium specimens and personal communications with numerous field biologists, we surveyed for Eriogonum corymbosum and related Eriogonum taxa from southern Nevada, northern Arizona, and northern New Mexico north through Utah and into Colorado. We collected leaf samples of 10-15 plants from each of 51 populations representing 12 Eriogonum species within subgenus Eucycla (Appendix 1; Table 1; Figs. 1, 2). Each collection site, referred to as a population, comprises a geographically bounded and relatively isolated group of potentially interbreeding individuals.

Leaf samples were dried rapidly on silica gel inside sealed plastic bags. Sampled populations included individuals from six varieties of $E$. corymbosum. We sampled 10 populations that we identified morphologically as E. corymbosum var. nilesii (Fig. 2), nine of which were located in and around Las Vegas, Nevada. Samples of the tenth population (N10) were collected from White Basin in the Muddy Mountains region about $40 \mathrm{~km}$ east of North Las Vegas. These 10 sites were all located in Clark County (referred to as variety nilesii). Additionally, samples from an eleventh Nevada population (referred to as N11) that appeared phenotypically most similar to variety nilesii were collected in Lincoln County about $15 \mathrm{~km}$ west of Utah's southwest corner and $100 \mathrm{~km}$ northeast of the Las Vegas plants (Fig. 2). Although there is only one confirmed population of variety aureum (which we sampled), we located and sampled three additional populations that keyed most closely to variety aureum, and in this paper we refer to them as such.

A protocol was followed at each collection site to avoid bias in the sample-selection process. After surveying to determine the general boundaries of a population, a central transect was marked through the length of the population. Plants were sampled by walking the transect and selecting consecutive plants near the transect that were at least $5 \mathrm{~m}$ apart (in order to avoid selecting clones). If too few plants were sampled following this method, plants were sampled further from the transect, while again ensuring they were at least $5 \mathrm{~m}$ from any other sampled plant. Ten to 15 leaves were collected per plant (more for taxa with very small leaves). Individual plants were sampled if they had enough healthy leaves (60 or more) to ensure that sampling would not be likely to cause lasting damage to the plant. Plants were not, however, selected based on size, apparent
TABLE 1. Seventeen Eriogonum taxa sampled from 51 populations. Identifications following Reveal (2005).

\begin{tabular}{ll}
\hline \hline \multicolumn{1}{c}{ Taxon } & Map Code \&\# of sites \\
\hline $\begin{array}{l}\text { Eriogonum corymbosum var. aureum (M. E. Jones) } \\
\quad \text { Reveal }\end{array}$ & Eca-4 \\
Eriogonum corymbosum var. corymbosum Benth. & Ecc-5 \\
Eriogonum corymbosum var. glutinosum M. E. Jones & Ecg-3 \\
Eriogonum corymbosum var. nilesii Reveal & Ecn-10 \\
Eriogonum corymbosum var. orbiculatum (S. Stokes) & Eco-5 \\
$\quad$ Reveal \& Brotherson & \\
Eriogonum corymbosum var. velutinum Reveal & Ecv-3 \\
Eriogonum corymbosum (variety undetermined) & N11-1 \\
Eriogonum effusum Nutt. & Ee-2 \\
Eriogonum brevicaule Nutt. & Eb-1 \\
Eriogonum hylophylum (Reveal \& Brotherson) & Eh-2 \\
S. L. Welsh & \\
Eriogonum lancifolium Reveal \& Brotherson & Ela-1 \\
Eriogonum leptocladon Torr. \& A. Gray & Ele-2 \\
Eriogonum loganum A. Nelson & Elo-1 \\
Eriogonum microthecum Nutt. & Em-2 \\
Eriogonum nummulare M. E. Jones & En-1 \\
Eriogonum racemosum Nutt. & Er-1 \\
Eriogonum smithii Reveal & Es-2 \\
Eriogonum thompsoniae S. Watson & Et-5 \\
\hline
\end{tabular}

age, or other morphological features. Plant vouchers for each collection site are deposited at UTC.

DNA Extraction-Genomic DNA was extracted from the dried leaf samples using the Qiagen DNeasy 96 Plant Kit and the Qiagen DNeasy Plant Mini Kit (Qiagen, Inc., Valencia, California) following the instructions of the manufacturer. Concentrations of DNA in the extracted sample solutions were quantified with the NanoDrop ND-1000 spectrophotometer (Nanodrop Technologies, Wilmington, Delaware). Extracted DNA solutions were stored at $-80^{\circ} \mathrm{C}$ until use.

Amplified Fragment Length Polymorphisms-An AFLP profile was generated for each DNA sample using a modified version of the protocol by Vos et al. (1995). The extracted DNA was digested with restriction enzymes (with the rare cutter EcoRI and the frequent cutter MseI) then ligated with forward and reverse adaptors. A subset of the fragments was amplified by polymerase chain reaction (PCR) using an EcoRI/MseI primer pair set, with an additional selective nucleotide on each primer: EcoRI+A and MseI+A. This +1 PCR reaction was followed by a +3 PCR reaction in which 2 additional selective nucleotides were added to the primer pair sets. We used two different +3 primer pair combinations with the +1 PCR product: EcoRI-ACG with MseI-ACT and EcoRI-ACC with MseI-AGC. The amplified restriction fragments were separated via capillary electrophoresis and recorded using Applied Biosystem's ABI 3730 DNA Analyzer with LIZ-500 size standards. The AFLP profile generated from each DNA sample was visualized and scored using Genographer v1.6.0 (Benham 2001). We replicated $32(8.2 \%)$ of the samples to determine the error rate in band scoring.

The AFLP technique amplifies regions of the genome randomly and many polymorphisms can be found, representing variation among individuals via presence or absence of restriction sites and the selective nucleotides. From the scored fragments generated by the +3 primer pair sets, we selected 103 polymorphic loci based on data quality and bimodality of signal across the dataset, varying in size from $66-476 \mathrm{bp}$, and obtained AFLP profiles from an average of eight plants per population (on which we based our analyses).

We examined the AFLP data with Principal Components Analysis (PCA) using the program NTSYSpc v. 2.10t (Rohlf 2000). This multivariate analysis constructs a set of three orthogonal coordinate axes from the first three eigenvalues (derived from the presence/absence data) and projects the individual samples as points in a scatter plot within these three axes such that variance is maximized in as few dimensions as possible. Representing the variance extracted by each axis, eigenvalues can be summed as a percentage of the total variance. This exploratory approach rapidly provides graphical $3-\mathrm{D}$ correlation matrices that demonstrate potential clustering.

For further insight into the data, we analyzed the AFLP sample profiles using a model-based method. The program Structure 2.2 utilizes a Bayesian approach to infer related clusters $(K)$ of individuals from multilocus genotype data while also evaluating the strength of evidence for 
the inferred clusters (Falush et al. 2007; Pritchard et al. 2000; Pritchard et al. 2007). Structure starts with an arbitrary parameter configuration that iteratively updates via a Markov Chain Monte Carlo (MCMC) algorithm until converging on the posterior distribution of all the parameters based on the data available (Pritchard et al. 2000). Each individual is assigned to a cluster according to its genetic makeup, represented by a vector $q$, which gives the percentages of that genetic makeup (if any) originating from each of the populations recognized by Structure. Although Structure was developed for diploid genotypic data that provide allelic information, Falush et al. (2007) extended the MCMC algorithm to account for the partial information provided by dominant markers (such as AFLPs).

We analyzed sampled populations of E. corymbosum var. nilesii, E. corymbosum var. aureum, E. thompsoniae, and population N11 with Structure set to the admixture model. We tested for the number of genetic clusters by running five replicates for each of six simulations, from $K=1$ to $K=6$, with 100,000 MCMC iterations after a burn-in of 30,000 (following Pritchard et al. 2000 and Pritchard et al. 2007).

Chloroplast Sequencing and Phylogenetic Analysis-We amplified and sequenced the trnS ${ }^{U G A}-\operatorname{trnf} M^{C A U} \mathrm{cpDNA}$ intergenic spacer region for 54 individuals from 13 different Eriogonum taxa using primers described by Shaw et al. (2005). We designed a third internal primer to ensure base clarity throughout the length of the cpDNA sequences. We amplified this region using PCRs in $50 \mu \mathrm{L}$ solutions and purified the PCR products using Qiagen's Qiaquick Purification Kits (Qiagen, Inc.). Sequencing reactions of the purified PCR products were run in both directions in separate reactions for each sample with each primer and Amersham's ET Dye Terminator.

The products of the sequencing reactions were purified through hydrated Sephadex and then run on the ABI 3100 automated capillary sequencer (Applied Biosystems). Contigs were assembled and sequences confirmed using Sequencher v.3.1.1 (Gene Codes, Ann Arbor, Michigan). The initial alignment for all sequences was obtained with the Clustal-W Multiple Alignment option in the BioEdit alignment program (Hall 1999). The final alignment was obtained manually, creating a trimmed sequence matrix with 1,222 characters. Nucleotide sequences are deposited in GenBank as accession numbers FJ204255 through FJ204308.

The aligned sequences were imported into PAUP v4.0b10 (Swofford 2002) and analyzed under the parsimony optimality criterion. All characters were analyzed as equal in weight and unordered, with gaps treated as missing. Tree space was examined with a heuristic search with simple addition sequence, the tree-bisection-reconnection (TBR) branch-swapping algorithm, and the MulTrees option in effect, keeping all trees. We used E. effusum samples to root the tree. Additionally, bootstrap values were calculated for 1,000 replicates and plotted onto the parsimony tree to evaluate relative branch support (Felsenstein 1985). The dataset for this phylogenetic analysis was submitted to TreeBASE (study number S2268).

\section{Results}

AFLP Reproducibility-Before running analyses on the AFLP matrix, we examined the similarity of the 32 AFLP replicates to assess the reproducibility of the data. The results from the replicated samples showed a locus-scoring error rate of $1.09 \%$ over 103 loci within the AFLP data matrix. This error rate is relatively low for AFLP studies (when rates are reported) and it should not bias our analytical results.

AFLPs: Principal Components Analyses-Princiapl components analysis 3-D graphs derived from the AFLP data matrix demonstrate genetic similarities among populations. The graphical distances of E. effusum and E. racemosum from the other taxa tested are apparent in Fig. 3. With those two taxa removed from the data matrix, a PCA analysis shows two large clusters (Fig. 4). One of these two main clusters is a broadly connected group composed of three subclusters: a subcluster of E. corymbosum var. nilesii samples at one end, a more loosely associated subcluster of E. thompsoniae samples at the other, and spread between these two subclusters are all the sampled individuals identified as E. corymbosum var. aureum as well as the Nevada population N11 from Lincoln County. Three individuals identified as E. corymbosum var. glutinosum are also part of this large cluster, most closely

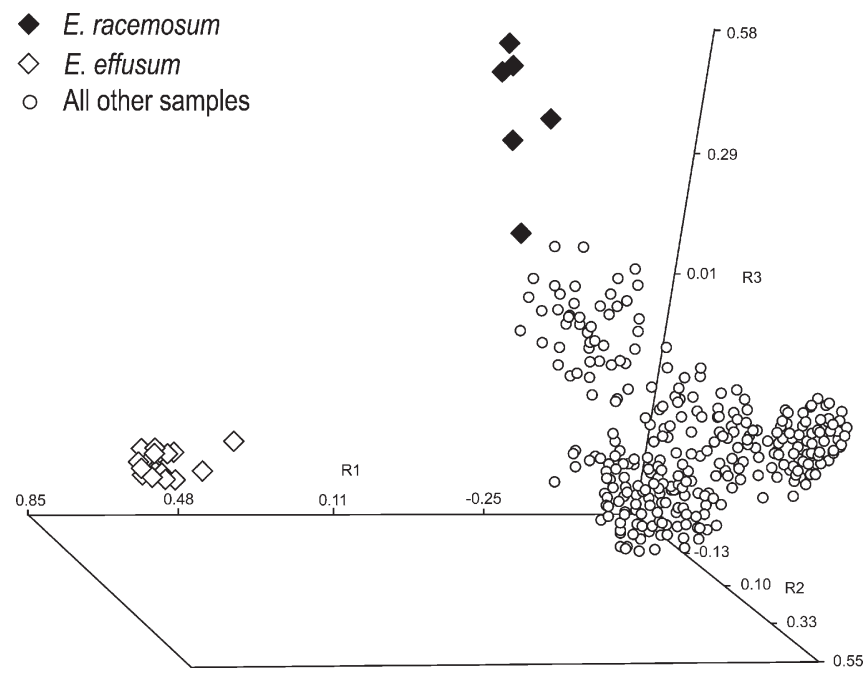

FIG. 3. PCA demonstrating the genetic divergence of E. effusum and E. racemosum samples from all others based on AFLP markers.

associated with the E. corymbosum var. nilesii subcluster. The second large cluster includes all other varieties of E. corymbosum (including 16 samples of E. corymbosum var. glutinosum from two populations) along with the remaining Eriogonum species.

To bring further clarity to the main cluster containing E. thompsoniae and E. corymbosum varieties nilesii and aureum, we ran another PCA with those individuals only, excluding the three members of E. corymbosum var. glutinosum (which will be examined more closely in another PCA). In Fig. 5, the samples of variety nilesii from the vicinity of Las Vegas (from populations N1-N9) and White Basin (population N10) can be seen as a tightly packed and separate cluster. The adjacent cluster, formed by members of variety aureum and the Lincoln

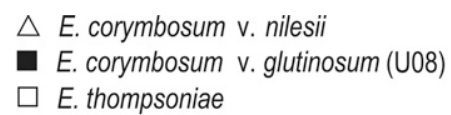

$\triangle$ E. corymbosum v. nilesii E. thompsoniae
E. corymbosum v. aureum

- E. corymbosum (N11)

All other samples, including two populations of v. glutinosum

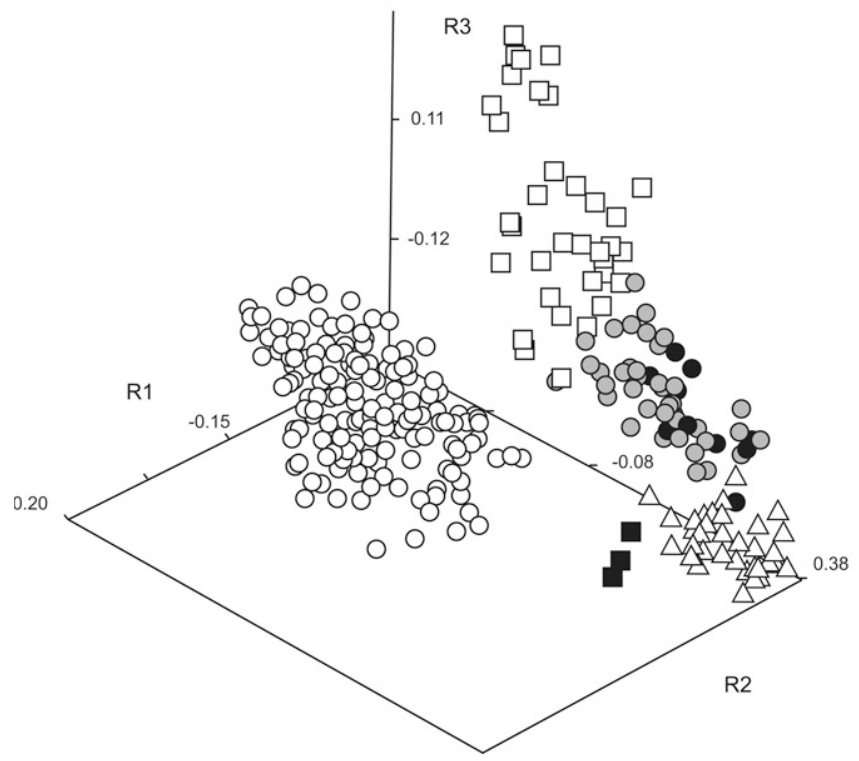

FIG. 4. PCA comparing samples of E. corymbosum var. nilesii, var. aureum, one population of var. glutinosum, and E. thompsoniae to each other and to all other samples tested based on AFLP markers. (Samples of E. effusum and E. racemosum were excluded). 
$\triangle$ E. corymbosum v. nilesii

O E. corymbosum v. aureum

- E. corymbosum (N11)

E. thompsoniae

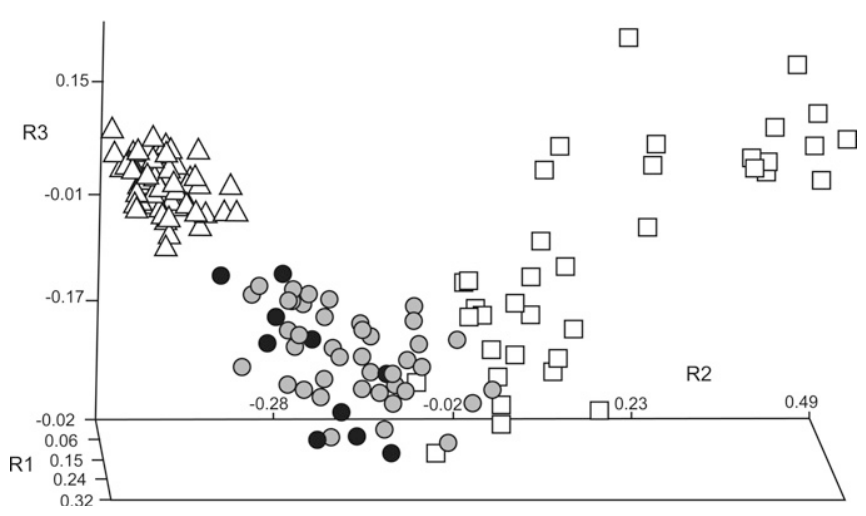

FIG. 5. PCA demonstrating relationship of E. corymbosum var. nilesii samples to the most closely related taxa, E. corymbosum var. aureum and E. thompsoniae, based on AFLP markers.

County plants (N11), bridges the gap between variety nilesii and $E$. thompsoniae with some overlap between a few samples from populations of E. thompsoniae and E. corymbosum var. aureum. The first three principal components captured 44.1, 8.6 , and $3.3 \%$ of the variance in the data set respectively.

Although there were too few samples of E. corymbosum var. glutinosum from U8 to draw any conclusions with confidence, we examined the graphical relationship between the three samples from U8 and the samples of E. corymbosum var. nilesii from populations N1-N10 in a separate PCA analysis (Fig. 6). The samples of variety glutinosum were peripheral to the cluster of variety nilesii samples.

AFLPs: Structure 2.2 Analyses-Using the program Structure 2.2 (Pritchard et al. 2007), we analyzed the AFLP profiles of all individuals sampled from populations designated as E. thompsoniae, E. corymbosum var. aureum, E. corymbosum var.

\section{$\triangle$ E. corymbosum v. nilesii}

E. corymbosum v. glutinosum (U08)

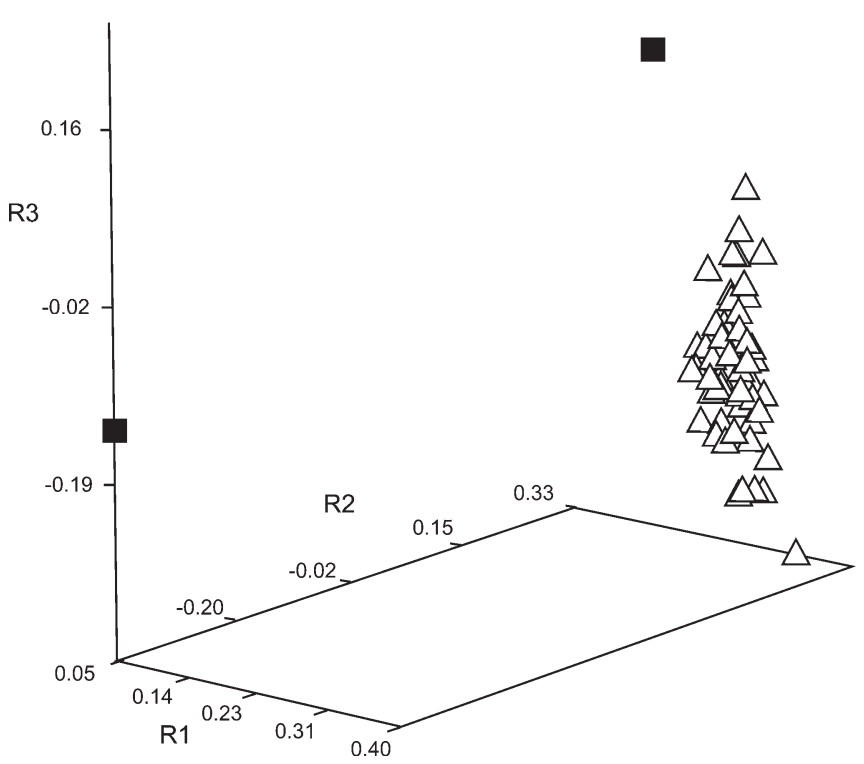

FIg. 6. PCA showing the relationship of E. corymbosum var. nilesii samples to three samples of E. corymbosum var. glutinosum (population U8). nilesii, and those from population N11. In our simulation tests to determine $K$, each increasingly larger $K$-value had a higher probability, but even at $K=6$ it was vanishingly small. We attributed this to the putative complexity of the populations in the St. George region of Washington County, Utah and population N11 in adjacent Lincoln County, Nevada. Such results are not infrequent when data sets are not all from genetically discrete populations, and in such cases it is recommended to choose a biologically reasonable value for $K$ that also appears to capture most of the structure (Pritchard et al. 2000; Pritchard et al. 2007). We therefore selected $K=3$ as a realistic estimation, given that three taxa were presumed to be involved. As with the PCA analyses, no population information was given for any of the individual AFLP profiles. Structure assigned each individual probabilistically to one of three clusters, but a number of apparently admixed individuals had affiliations with more than one cluster.

With the Structure output arranged with the individuals in order by presumed taxon (Fig. 7), the cluster of all individuals from the Clark County populations of E. corymbosum var. nilesii showed little evidence of admixture from the other two groups. However, many of the individuals in the second group (composed of all the E. corymbosum var. aureum samples and the samples from population N11) showed admixture from both of the other two clusters. The third cluster, composed of samples identified as E. thompsoniae, included some that showed admixture as well, especially from members of E. corymbosum var. aureum populations.

Chloroplast Sequence Analyses-Among the 13 taxa and 54 individuals we successfully sequenced, there were 17 different haplotypes due to 24 substitutions and 10 indels. Of the 24 variable characters in the PAUP parsimony analysis, 21 were parsimony-informative.

The analysis found a single most parsimonious tree (Fig. 8). All Clark County, Nevada samples of E. corymbosum var. nilesii had identical sequences, and shared their haplotype with individuals from two populations of E. corymbosum var. aureum (U35 and U36) and one population of E. thompsoniae (U32). The haplotype most similar, but not identical, to that of the Clark County, Nevada samples of E. corymbosum var. nilesii was shared by the two samples from population N11 (Lincoln County, Nevada), an E. corymbosum var. glutinosum sample from U08, and members of two other populations of E. thompsoniae (U19 and U33).

\section{Discussion}

The populations of E. corymbosum in Clark County, Nevada, have been grouped at different times in the past with two established varieties, either variety glutinosum or variety aureum, based on habit and flower color, among other phenotypic traits (Reveal 1967, 1985, 2002). Recently, Reveal (2004a) argued that the Clark County populations were morphologically and ecologically distinct enough to warrant a new taxonomic designation, which he named variety nilesii. Our comparison of the Clark County populations, using AFLP markers and cpDNA sequence data, supports Reveal's conclusions. We found demonstrable genetic cohesion among E. corymbosum individuals sampled from populations in Clark County, Nevada. Not only did the sampled individuals form a tight group isolated from sampled populations of other E. corymbosum varieties and related species in both PCA and Structure analyses, the Structure analysis also demonstrated 


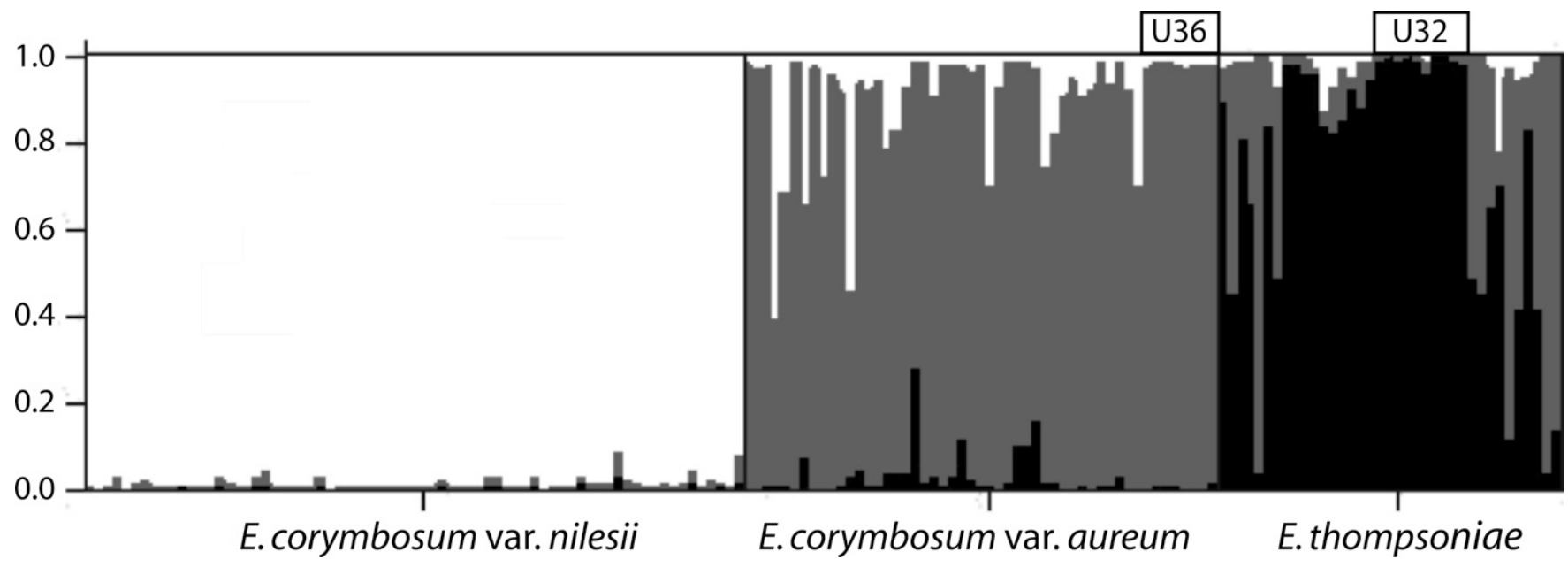

FIG. 7. Structure 2.2 bar graph of three taxa in order of populations sampled. Cluster membership is color coded, with white for Cluster 1 (corresponding to E. corymbosum var. nilesii populations N1-N10), gray for Cluster 2 (members of E. corymbosum var. aureum populations plus N11), and black for Cluster 3 (members of $E$. thompsoniae populations). Each bar represents an individual, with proportions of the 3 colors in each based on shared genetic profiles from the three clusters identified by Structure.

that they are independent from their most closely related taxa (demonstrating little or no evidence of introgression).

Eriogonum corymbosum var. aureum, the taxon which we attributed to a number of populations in and around St. George, Utah, appears to be the closest relative of E. corymbosum var. nilesii. We also found an apparent relationship between the predominantly herbaceous species E. thompsoniae and E. corymbosum var. nilesii, linked by their mutual relationships to E. corymbosum var. aureum. Although a geographically distant and morphologically distinct population of E. corymbosum var. glutinosum with only three individuals tested (U8 in Appendix 1) needs further examination, all other Eriogonum varieties and species that we tested (including two other populations of variety glutinosum) were members of more distantly related clusters in our analyses.

The relationships of E. corymbosum var. nilesii to variety aureum and E. thompsoniae are demonstrable in our AFLP and sequence results. Although variety nilesii forms a tight and separate cluster in our PCA analyses (Figs. 4-6) and Structure analysis (Fig. 7), the association of this taxon with the loosely formed cluster that includes variety aureum and E. thompsoniae may be the result of its past migration and hybridization with Eriogonum taxa in Utah. Given that the Structure and NTSYS programs employ different algorithms to group the genetic profiles of samples, the similar clustering arrangements they provided add corroborative support to our conclusions. The sequence analysis adds additional evidence that $E$. corymbosum var. nilesii is a distinct taxon whose nearest relative is variety aureum. These results indicate that variety aureum may be a hybrid and repository of genes from both variety nilesii and E. thompsoniae, thereby providing a conduit for introgression between them. In that regard, the Structure analysis shows introgression by attributes characteristic of E. corymbosoum var. nilesii into both E. corymbosum var. aureum and E. thompsoniae, but no obvious evidence of the reverse (Fig. 7).

While PCA analyses show a clear genetic separation of E. corymbosum var. nilesii and E. thompsoniae (Figs. 4, 5), the Structure analysis suggests that a number of E. thompsoniae individuals share genetic characters with E. nilesii (Fig. 7). Interestingly, the E. thompsoniae population that appears in our AFLP tests to be least influenced by E. corymbosum var. nilesii or var. aureum (U32; Fig. 7) shares the cpDNA haplotype common to all the Clark County samples of variety nilesii (Fig. 8), echoing the Structure findings. So even this distinctive E. thompsoniae population may have a historical relationship with E. corymbosum var. nilesii.

The loose relationships between the samples of E. corymbosum var. aureum and E. thompsoniae, the broad spread of their genetic variability and the degree of overlap between the two taxa as demonstrated in Fig. 5, suggest continuing migration and hybridization. The region of southern Utah bordering southern Nevada and northern Arizona, where E. thompsoniae and E. corymbosum var. aureum populations are found, appears to be a zone of hybridization between these two taxa, and contributions to these populations from E. corymbosum var. nilesii may explain the patterns we found in our analyses. Perhaps not coincidentally, this region is also a transition zone between the Mojave desert (which encompasses Clark County's populations of variety nilesii) and the southwestern portion of the Colorado Plateau (the region where variety aureum and E. thompsoniae reside). Population N11 apparently lies on a contact zone between taxa from the two regions.

In contrast, the relatively cohesive nature of Clark County's E. corymbosum var. nilesii samples (Figs. 5, 6) suggests little influence on those populations by either E. corymbosum var. aureum or E. thompsoniae. This distinctness is also apparent in the Structure analysis, with little or no evidence of introgression from either E. corymbosum var. aureum or E. thompsoniae apparent in the Clark County samples (Fig. 7). Thus, the patterns we found may be the result of the long establishment of E. corymbosum var. nilesii as a distinct taxon while genetic exchange between populations of E. corymbosum var. aureum and E. thompsoniae appears to be ongoing.

Taxonomic Designation-The species taxon, as the fundamental unit of evolution, is unique among taxonomic ranks. The species taxon designates a cohesive metapopulation composed of sexually reproductive organisms forming a separate lineage on its own evolutionary trajectory (Zimmerman 1959; Simpson 1961; Hennig 1966; Mayr 2000; Wiley and Mayden 2000; Ghiselin 2002; De Queiroz 2005; Rieseberg et al. 2006). The infraspecific taxon 'variety', on the other hand, denotes a population or group of populations presumed to have 
60.1

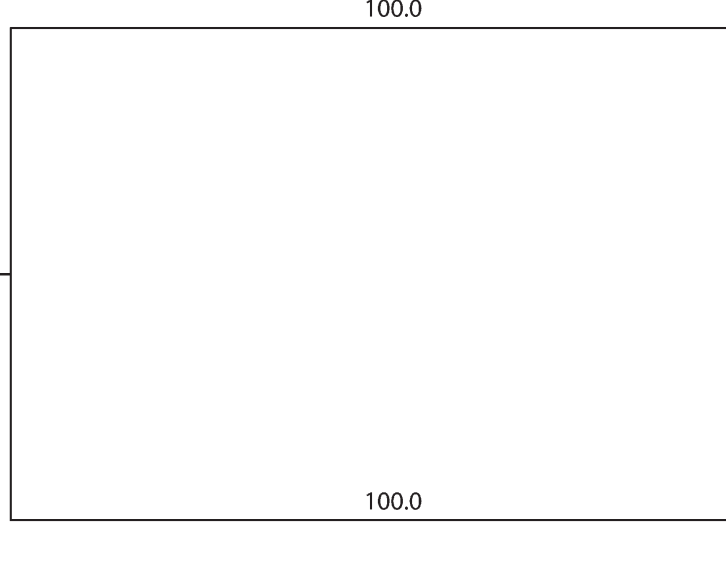

64.2

60.9

E. smithii $\mathrm{U} 2709$

E. smithii $\mathrm{U} 2710$

E. effusum $\mathrm{C} 0102$

E. effusum $\mathrm{C} 0206$
E. corymbosum nilesii $\mathrm{N} 0107$

E. corymbosum nilesii $\mathrm{N} 0108$

E. corymbosum nilesii $\mathrm{N} 0202$

E. corymbosum nilesii $\mathrm{N} 0203$

E. corymbosum nilesii $\mathrm{N} 0215$

E. corymbosum nilesii $\mathrm{N} 0308$

E. corymbosum nilesii $\mathrm{N} 0403$

E. corymbosum nilesii $\mathrm{N} 0504$

E. corymbosum nilesii $\mathrm{N} 0505$

E. corymbosum nilesii $\mathrm{N} 0704$

E. corymbosum nilesii $\mathrm{N} 0705$

E. corymbosum nilesii $\mathrm{N} 0807$

E. corymbosum aureum U3504

E. corymbosum aureum U3609

E. corymbosum aureum U3610

E. thompsoniae U3209

E. thompsoniae U3210

E. thompsoniae U1902

E. thompsoniae U3310

E. corymbosum $\mathrm{N} 1101$

E. corymbosum $\mathrm{N} 1108$

E. corymbosum glutinosum $\cup 0814$

E. smithii U2609

E. smithii $\mathrm{U} 2610$

E. corymbosum orbiculatum U1114

E. corymbosum orbiculatum U3010 95.0

E. corymbosum velutinum $\mathrm{U} 2909$

E. corymbosum velutinum $U 2910$

E. hylophilum U2003

E. hylophilum U2010

58.9 E. corymbosum corymbosum U2209

E. corymbosum corymbosum U2210

E. corymbosum corymbosum U1204

E. corymbosum corymbosum U1205

E. corymbosum glutinosum U1403

E. hylophilum $\mathrm{U} 2101$

E. hylophilum $\mathrm{U} 2106$

E. hylophilum $\mathrm{U} 2107$

E. lancifolium U2409

E. lancifolium $\mathrm{U} 2410$

E. corymbosum velutinum $\mathrm{U} 2809$

E. corymbosum velutinum $\mathrm{U} 2810$

E. corymbosum corymbosum U0914

E. leptocladon U2509

E. corymbosum velutinum $\mathrm{A} 0207$

E. leptocladon U1505

E. microthecum U1802

E. microthecum U1803

E. effusum $\mathrm{CO207}$

2.0

FIG. 8. Most parsimonious tree from a parsimony analysis of 13 Eriogonum taxa based on sequences of the trnS/trnfM cpDNA region. Branch numbers are bootstrap values.

the potential to eventually gain the necessary separation to achieve their own evolutionary path. But where does one draw the line? Charles Darwin's (1875) view of varieties as "incipient species" remains conceptually accepted today, but he provided no methodology of discerning such taxa. O'Brien and Mayr (1991) suggested that populations could be recog- nized as subspecies if 1) their members can be identified by phylogenetically concordant phenotypic traits, 2) they are found in a unique habitat or geographic range, and 3) they demonstrate a unique natural history compared to any other subdivisions within the species. The apparently disjunct set of Clark County populations of E. corymbosum var. nilesii meets 
these requirements. But phenotypic traits might not be genetically based (Haig et al. 2006), particularly in plants (which can show edaphic and other environmental effects phenotypically), and the geographic separation might merely demonstrate distance but not divergence. More is required than a phenotypically diagnosable population or set of populations within a defined geographic range and habitat in order to demonstrate potential evolutionary independence.

The seventy-five percent rule provides a quantitative, although arbitrary, method whereby $75 \%$ of the members of the population of interest must be separable from all members that make up the overlapping population (Amadon 1949; Patten and Unitt 2002). This method also suffers from the subjective approach to choosing characters used to determine any overlap. Still, although some members of the Clark County populations of E. corymbosum var. nilesii show a close relationship to E. corymbosum var. aureum in all our AFLP-based analyses, there is no overlap. If we identify the population N11 as part of E. corymbosum var. nilesii (based only on morphological similarity) then the proportion of members separable in our AFLP tests becomes $88 \%$, and the criterion is also met.

A more effective approach to assigning infraspecific designations to populations of sexually reproductive organisms is to demonstrate multiple lines of mutually corroborative evidence that demonstrate the populations as distinctive entities evolutionarily (Haig et al. 2006). We have shown here the genetic cohesion between E. corymbosum var. nilesii samples and their divergence from all other closely related taxa tested, using AFLP and cpDNA markers. Our results corroborate Reveal's (2005) description of E. corymbosum var. nilesii's unique geographic range, habitat, and morphological distinctiveness in relation to other varieties. Some of the phenotypic characters Reveal examined, such as leaves that are "whitelanate to densely white-tomentose abaxially, silvery-floccose adaxially," also suggest the adaptive divergence of E. corymbosum var. nilesii, making it particularly well suited to the harsh desert climate of the Mojave. And the suggestion that E. corymbosum var. nilesii may be an edaphic "extremophile" (Drohan et al. 2006) adds further support to its adaptive divergence. Given these multiple lines of evidence for the cohesion of Nevada's Clark County populations and their evolutionary divergence from other populations of E. corymbosum, the description of the set of Clark County populations as variety nilesii is strongly supported.

One might argue, given the confluence of evidence for genetic cohesion between the subpopulations in Clark County and their evolutionary divergence from other taxa, that $E$. corymbosum var. nilesii populations form a metapopulation that deserves recognition as a species rather than a variety. Its apparent allopatry, possible edaphic endemism, and ecological value to the Mojave ecosystem all suggest its existence as a separate taxonomic entity on its own evolutionary trajectory. But its close genetic association to E. corymbosum var. aureum and one population of var. glutinosum, and its morphological similarity to the N11 population, provide a gray area that requires further study with wider sampling before one might conclude that Nevada's Clark County populations constitute a unique species of buckwheat.

Future Work-The similarity found between E. corymbosum var. nilesii and one population of E. corymbosum var. glutinosum should be examined more closely. It is possible that E. corymbosum var. aureum is the result of hybridization between E. corymbosum var. nilesii migrants and E. thompsoniae, and that E. corymbosum var. nilesii is a long-established metapopulation that may have diverged from a variety like E. corymbosum var. glutinosum.

It has been suggested that E. corymbosum var. nilesii is an edaphic "extremophile" that may have established a niche in the soils derived from a Pleistocene marsh environment and now found in arid Mojave regions of Clark County, Nevada (Drohan et al. 2006). Perhaps soil endemism provides the isolation to protect this distinctive variety of E. corymbosum from introgression by other taxa, maintaining the stability of this metapopulation. Further work to verify the edaphic regime of E. corymbosum var. nilesii would be worth pursuing.

An ecological study of the structural importance of E. corymbosum var. nilesii on the landscape would be a valuable contribution since it appears to be the dominant plant species in the places where it thrives. Its cover percentages relative to other plant taxa appears to be significant, its soil holding properties may be important, and its relationships with other organisms may be extensive. Finally, an examination of ploidy levels could provide a clearer picture of the relationships within the E. corymbosum complex, and provide a window into the history of hybridization within this group.

AcKnowledgments. This work was supported by grants from the U.S. Fish and Wildlife Service and a NNPS Margaret Williams Research Grant. Thanks to Gina Glenne, John Anderson, and Jerry Tiehm for help in directing us to collection sites. Thanks to Dr. James Reveal for advice and some voucher identifications. We are also grateful to Carol Rowe, Lee Bjerregaard, Carrie Drake, Usha Menon, Colin Brammer, Aaron Duffy, Annie Jensen, Andrea Bell, and others for their ideas, assistance, and editorial comments. Thanks to Ann Lamb-Frye and an anonymous reviewer for helpful comments on an earlier version of the manuscript.

\section{Literature Cited}

Archibald, J. K., P. G. Wolf, V. J. Tepedino, and J. Bair. 2001. Genetic relationships and population structure of the endangered Steamboat buckwheat, Eriogonum ovalifolium var. williamsiae (Polygonaceae). American Journal of Botany 88: 608-615.

Amadon, D. 1949. The seventy-five per cent rule for subspecies. The Condor 51: 250-258.

Arnott, G. A. W. 1832. Botany. Pp. 30-145 in Encyclopedia Britannica ed. 7, 5, ed. M. Napier. Edinburgh: Adam Black.

Benham, J. J. 2001. Genographer Version 1.6.0. URL http:/ / hordeum.oscs. montana.edu/genographer.

Boettinger, J. L., G. Busch, A. Croft, T. C. Edwards Jr., B. Jennings, R. S. Krannich, E. Leydsman, J. A. Macmahon, and R. E. Toth. 2007. Upper Las Vegas Wash Conservation Transfer Area: a system to develop alternative scenarios. Logan: Utah State University.

Chase, M. W., D. E. Soltis, R. G. Olmstead, D. Morgan, D. H. Les, B. D. Mishler, M. R. Duvall, R. A. Price, H. G. Hills, Y. L. Qiu, K. A. Kron, J. H. Rettig, E. Conti, J. D. Palmer, J. R. Manhart, K. J. Sytsma, H. J. Michaels, W. J. Kress, K. G. Karol, W. D. Clark, M. Hedren, B. S. Gaut, R. K. Jansen, K. J. Kim, C. F. Wimpee, J. F. Smith, G. R. Furnier, S. H. Strauss, Q. Y. Xiang, G. M. Plunkett, P. S. Soltis, S. M. Swensen, S. E. Williams, P. A. Gadek, C. J. Quinn, L. E. Eguiarte, E. Golenberg, G. H. Learn, S. W. Graham, S. C. H. Barrett, S. Dayanandan, and V. A. Albert. 1993. Phylogenetics of seed plants-an analysis of nucleotide sequences from the plastid gene $r b c L$. Annals of the Missouri Botanical Garden 80: 528-580.

Comes, H. P. and J. W. Kadereit. 1998. The effect of Quaternary climatic changes on plant distribution and evolution. Trends in Plant Science 3: $432-438$.

Cuenoud, P., V. Savolainen, L. W. Chatrou, M. Powell, R. J. Grayer, and M. W. Chase. 2002. Molecular phylogenetics of Caryophyllales based on nuclear $18 S$ rDNA and plastid $r b c L$, atpB, and matK DNA sequences. American Journal of Botany 89: 132-144.

Darwin, C. R. 1875. The variation of animals and plants under domestication. London: John Murray.

De Queiroz, K. 2005. Different species problems and their resolution. BioEssays 27: 1263-1269. 
Douglas, N. A. and P. S. Manos. 2007. Molecular phylogeny of Nyctaginaceae: taxonomy, biogeography, and characters associated with a radiation of xerophytic genera in North America. American Journal of Botany 94: 856-872.

Drohan, P. J., B. J. Buck, and D. J. Merkler. 2006. Gypsophile or extremophile? A case study examining the relationship between gypsum soils and the rare species that occur on them. 18th World Congress of Soil Science. Abstracts with Programs. Philadelphia: International Union of Soil Scientists.

Falush, D., M. Stephens, and J. K. Pritchard. 2007. Inference of population structure using multilocus genotype data: dominant markers and null alleles. Molecular Ecology Notes 7: 574-578.

Fehlberg, S. D. and T. A. Ranker. 2009. Evolutionary history and phylogeography of Encelia farinosa (Asteraceae) from the Sonoran, Mojave, and Peninsular Deserts. Molecular Phylogenetics and Evolution 50: 326-335.

Felsenstein, 1985. Confidence limits on phylogenies: an approach using the bootstrap. Evolution 39: 783-791.

Freeman, C. C. and J. L. Reveal. 2005. Polygonaceae. Pp. 216-218 in Flora of North America. 12+ vols, ed. Flora of North America Editorial Committee. New York: Oxford University Press.

Ghiselin, M. T. 2002. Species concepts: the basis for controversy and reconciliation. Fish and Fisheries 3: 151-160.

Haig, S. M., E. A. Beever, S. M. Chambers, H. M. Draheim, B. D. Dugger, S. Dunham, E. Elliott-Smith, J. B. Fontaine, D. C. Kesler, B. J. Knaus, I. F. Lopes, P. Loschl, T. D. Mullins, and L. M. Sheffield. 2006. Taxonomic considerations in listing subspecies under the U.S. Endangered Species Act. Conservation Biology 20: 1584-1594

Hall, T. A. 1999. BioEdit: a user-friendly biological sequence alignment editor and analysis program for Windows 95/98/NT. Nucleic Acids Symposium Series 41: 95-98.

Hennig, W. 1966. Phylogenetic systematics. Urbana: University of Illinois Press.

Jones, M. E. 1903. Eriogonum. Contributions to Western Botany 11: 4-18.

Lamb-Frye, A. S. and K. A. Kron. 2003. rbcL phylogeny and character evolution in Polygonaceae. Systematic Botany 28: 326-332.

Lledo, M. D., M. B. Crespo, K. M. Cameron, M. F. Fay, and M. W. Chase. 1998. Systematics of Plumbaginaceae based upon cladistic analysis of rbcL sequence data. Systematic Botany 23: 21-29.

Luerssen, C. 1882. Handbuch der systematischen Botanik mit besonderer Berücksichtigung der Arzneipflanzen bearbeitet. II. Band: Phanerogamen. Leipzig: H. Haessel.

Maschinski, J., J. E. Baggs, and C. F. Sacchi. 2004. Seedling recruitment and survival of an endangered limestone endemic in its natural habitat and experimental reintroduction sites. American Journal of Botany 91: 689-698.

Mayr, E. 2000. The biological species concept. Pp. 17-29 in Species concepts and phylogenetic theory: a debate, eds. Q. D. Wheeler and R. Meier. New York: Columbia University Press.

Meyer, S. E. 1986. The ecology of gypsophile endemism in the eastern Mojave Desert. Ecology 67: 1303-1313.

Moore, M. J. and R. K. Jansen. 2007. Origins and biogeography of gypsophily in the Chihuahuan Desert plant group Tiquilia Subg. Eddya (Boraginaceae). Systematic Botany 32: 392-414.

Nickrent, D. L. and D.Wiens. 1989. Genetic diversity in the rare California shrub Dedeckera eurekensis (Polygonaceae). Systematic Botany 14: 245-253.

O'Brien, S. J. and E. Mayr. 1991. Bureaucratic mischief: recognizing endangered species and subspecies. Science 251: 1187-1188.

Patten, M. A. and P. Unitt. 2002. Diagnosability versus mean differences of sage sparrow subspecies. The Condor 119: 26-35.

Perkins, M. and E. Samargo. 2008. Updated ESA Candidate List Released. The Wildife Policy News 18: 1-10.

Pritchard, J. K., M. Stephens, and P. Donnelly. 2000. Inference of population structure using multilocus genotype data. Genetics 155: 945-959.

Pritchard, J. K., X. Wen, and D. Falush. 2007. Documentation for structure software: version 2.2. Available from http:/ / pritch.bsd.uchicago. edu/software/structure22/readme.pdf.

Reveal, J. L. 1967. Notes on Eriogonum - V: A revision of the Eriogonum corymbosum complex. The Great Basin Naturalist 27: 183-229.

Reveal, J. L. 1978. Distribution and phylogeny of Eriogonoideae (Polygonaceae). Great Basin Naturalist Memoirs 2: 169-190.

Reveal, J. L. 1983. The Demoulin Rule and newly mandated combinations in Eriogonum (Polygonaceae). Taxon 72: 292-295.

Reveal, J. L. 1985. Annotated key to Eriogonum (Polygonaceae) of Nevada. The Great Basin Naturalist 45: 493-519.
Reveal, J. L. 1989. The Eriogonoid flora of California (Polygonaceae: Eriogonoideae). Phytologia 66: 295-414.

Reveal, J. L. 2002. A review of Eriogonum corymbosum Benth. with emphasis on the species in southern Nevada. Las Vegas: U.S. Fish and Wildlife Service.

Reveal,J. L. 2004a. New entities in Eriogonum (Polygonaceae: Eriogonoideae). Phytologia 86: 121-159.

Reveal, J. L. 2004b. Proposal to conserve the name Gilmania Coville against Phyllogonum Coville (Polygonaceae: Eriogonoideae) - a case of mistaken homonymy. Taxon 53: 573.

Reveal, J. L. 2005. Polygonaceae: subfamily Eriogonoideae. Pp. 218-478 in Flora of North America. 12+ vols, ed. Flora of North America Editorial Committee. New York: Oxford University Press.

Rieseberg, L. H., T. E. Wood, and E. J. Baack. 2006. The nature of plant species. Nature 440: 524-527.

Roberty, G. and S. Vautier. 1964. Les genres de Polygonaceés. Boissiera 10: $7-128$.

Rohlf, F. J. 2000. NTSYSpc: Numerical Taxonomy and Multivariate Analysis System, ver. 2.1t. Setauket, New York: Exeter Software.

Sanchez, A. and K. A. Kron. 2008. Phylogenetics of Polygonaceae with an emphasis on the evolution of Eriogonoideae. Systematic Botany 33: 87-96.

Sivinski, R. C. and P. J. Knight. 1996. Narrow endemism in the New Mexico flora. Pp. 286-296 in Southwestern rare and endangered plants: proceedings of the second conference, eds. J. Maschinski, H. D. Hammond, and L. Holter Fort Collins: U.S. Department of Agriculture, Forest Service, Rocky Mountain Forest and Range Experiment Station.

Shaw, J., E. B. Lickey, J. T. Beck, S. B. Farmer, W. Liu, J. Miller, K. C. Siripun, C. T. Winder, E. E. Schilling, and R. L. Small. 2005. The tortoise and the hare II: relative utility of 21 noncoding chloroplast DNA sequences for phylogenetic analysis. American Journal of Botany 92: 142-166.

Simpson, G. G. 1961. Principles of animal taxonomy. New York: Columbia University Press.

Swofford, D. L. 2002. PAUP*: Phylogenetic analysis using parsimony (*and other methods), version 4.0b10. Sunderland: Sinauer Associates.

USFWS. 1983. Endangered and threatened species listing and recovery priority guidelines. Federal Register 48: 43098-43105.

Vos, P., R. Hogers, M. Bleeker, M. Reijans, T. V. D. Lee, M. Hornes, A. Friters, J. Pot, J. Paleman, M. Kuiper, and M. Zabeau. 1995. AFLP: a new technique for DNA fingerprinting. Nucleic Acids Research 23: 4407-4414.

Welsh, S. L. 1978. Problems in plant endemism on the Colorado Plateau. Memoirs of the Great Basin Naturalist 2: 191-196.

Welsh, S. L., N. D. Atwood, S. Goodrich, and L. C. Higgins. 2003. A Utah flora. Provo: Monte L. Bean Life Science Museum, Brigham Young University.

Wiley, E. O. and R. L. Mayden. 2000. The Evolutionary Species Concept. Pp. 70-89 in Species concepts and phylogenetic theory: a debate, eds. Q. D. Wheeler and R. Meier. New York: Columbia University Press.

Zimmerman, W. 1959. Die Phylogenie der Pflanzen. Stuttgart: Gustav Fischer Verlag.

ApPENDIx 1. Eriogonum collection sites listed in alphabetical order by: taxon; coded site name; general location; latitude and longitude.

E. brevicaule; U07; City Canyon, Salt Lake Co, UT; N40 48' 29.9" W111 ${ }^{\circ}$ $52^{\prime} 2.3^{\prime \prime}$. E. corymbosum aureum; U01; Shivwits, Washington Co, UT; N37 $10^{\prime}$ 53.5" W113 46' 9.2"; U34; Washington, Washington Co, UT; N37 $7^{\prime}$ 51.9" W113 29' 9.4"; U35; Beehive Dome, Washington Co, UT; N37 $0^{\prime}$

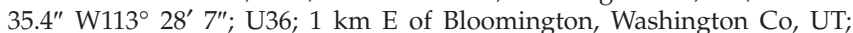
$\mathrm{N} 37^{\circ} 3^{\prime} 4.2^{\prime \prime} \mathrm{W} 113^{\circ} 34^{\prime} 25.4^{\prime \prime}$. E. corymbosum corymbosum; U09; Escalante, Garfield Co, UT; N37 $47^{\prime}$ 6.9" W111 ${ }^{\circ} 37^{\prime}$ 52.5"; U12; Grover, Wayne Co, UT; N38 $13^{\prime} 36.9^{\prime \prime}$ W111 $20^{\prime} 48.2^{\prime \prime}$; U13; 3.5 km NW of Grover, Wayne Co, UT; N38 $15^{\prime}$ 1.7" W111 22' 26.5"; U22; Middle 9-Mile Canyon, Carbon Co, UT; N39 46 $32.9^{\prime \prime}$ W110 28' 47.1"; U23; Middle 9-Mile Canyon, Carbon $\mathrm{Co}, \mathrm{UT} ; \mathrm{N} 39^{\circ} 46^{\prime} 30.2^{\prime \prime} \mathrm{W} 110^{\circ} 27^{\prime} 21.1^{\prime \prime}$. E. corymbosum glutinosum; U08; $16 \mathrm{~km}$ NE of Henrieville, Garfield Co, UT; N37 $38^{\prime} 20.4^{\prime \prime}$ W111 $50^{\circ} 37.8^{\prime \prime}$; U14; 2 km S of Fruita, Wayne Co, UT; N38 $15^{\prime} 59.4^{\prime \prime}$ W111 $14^{\prime} 41.3^{\prime \prime}$; A01; $9 \mathrm{~km} \mathrm{~S}$ of Page, Coconino County, AZ.; N36 50' 15.5" W111 $30^{\prime} 31.1^{\prime \prime}$. E. corymbosum nilesii; N01; N Las Vegas, Clark Co, NV; N36 $17^{\prime} 29.4^{\prime \prime}$ W115 $11^{\prime}$ 47.1"; N02; N Las Vegas, Clark Co, NV; N36 $18^{\prime} 52.1^{\prime \prime}$ W115 $11^{\prime} 35.8^{\prime \prime}$; N03; NW Las Vegas, Clark Co, NV; N36 14' 54.5" W115 9' 20.6"; N04; NW Las Vegas, Clark Co, NV; N36 $14^{\prime} 16.9^{\prime \prime}$ W115 $9^{\prime} 34.7^{\prime \prime}$; N05; NW Las Vegas, Clark Co, NV; N36 $14^{\prime} 35.4^{\prime \prime}$ W115 4' 45.3"; N06; NW Las Vegas, Clark Co, NV; N36 $15^{\prime} 30.2^{\prime \prime}$ W115 $4^{\prime}$ 22.7"; N07; S Las Vegas, Clark Co, NV; N36 6' 14.9" W115 12' 29.7"; N08; NW Las Vegas, Clark Co, NV; 
$\mathrm{N} 36^{\circ} 15^{\prime}$ 58.2" W115 $4^{\prime}$ 43. $5^{\prime \prime}$; N09; NW Las Vegas, Clark Co, NV; N36 $14^{\prime}$ 59.6" W115 8' 7.0"; N10; White Basin, Clark County, NV; N36 20' 26.7" W114 $33^{\prime} 37.3^{\prime \prime}$. E. corymbosum N11; N11; $22 \mathrm{~km}$ nw of Mesquite, AZ in Lincoln Co, NV; N36 57' 42.1" W114 ${ }^{\circ} 13^{\prime}$ 5.8." E. corymbosum orbiculatum; U11; $14 \mathrm{~km}$ E of Escalante, Garfield Co, UT; N37 $44^{\prime} 58.6^{\prime \prime}$ W111 $26^{\prime}$ 38.0"; U16; $15 \mathrm{~km} \mathrm{~W}$ of Hanksville, Wayne Co, UT; N38 21' 56.9" W110 53' 11.9"; U17; Three Forks, Wayne Co, UT; N38 $0^{\prime} 2.5^{\prime \prime}$ W110 30' 46.4"; U30; Arches, Grand Co, UT; N38 37' 3.8" W109 37' 5.4"; U31; $22 \mathrm{~km} \mathrm{~S} \mathrm{of}$ Mexican Hat, San Juan Co, UT; N37 $3^{\prime}$ 21.5" W110 5' 27.3." E. corymbosum velutinum; U28; $17 \mathrm{~km}$ NE of Bluff, San Juan Co, UT; N37 $25^{\prime} 5.8^{\prime \prime}$ W109 26' 47.1"; U29; Bluff, San Juan Co, UT; N37 $17^{\prime} 21.8^{\prime \prime}$ W109 $32^{\prime}$ 53.6"; A02; $13 \mathrm{~km}$ E of Kayenta, Navajo Co, AZ; N36 ${ }^{\circ} 43^{\prime} 48.7^{\prime \prime}$ W110 $6^{\prime}$ 42.0". E. effusum; C01; $12 \mathrm{~km}$ NW of Salida, Chaffee Co, Co; N38 $37^{\prime} 12.5^{\prime \prime}$ W106 $4^{\prime} 42.1^{\prime \prime} ; \mathrm{C} 02 ; 13 \mathrm{~km}$ NW of Salida, Chaffee Co, Co; N38 $37^{\prime} 59.4^{\prime \prime}$ W106 $4^{\prime} 45.7^{\prime \prime}$. E. hylophilum; U20; Upper 9-Mile Canyon, Duchesne Co, UT; N39 52' 57.9" W110 13' 51.1"; U21; Upper 9-Mile Canyon, Duchesne $\mathrm{Co}, \mathrm{UT}$; N39 $52^{\prime} 57.2^{\prime \prime} \mathrm{W} 110^{\circ} 14^{\prime} 6.0^{\prime \prime}$. E. lancifolium; U24; $8 \mathrm{~km}$ E of
Wellington, Carbon Co, UT; N39 32' 48.3" W110 38' 34.6". E. leptocladon;

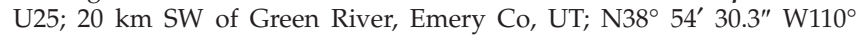
22' 10.0"; U15; $3 \mathrm{~km} \mathrm{~S}$ of Hanksville, Wayne Co, UT; N38 ${ }^{\circ} 20^{\prime} 40.1^{\prime \prime}$ W110 $42^{\prime} 23.6^{\prime \prime}$. E. loganum; U06; Logan, Cache Co, UT; N41 ${ }^{\circ} 44^{\prime} 25.2^{\prime \prime}$ W $111^{\circ} 48^{\prime}$ 25.5". E. microthecum simpsonii; NM1; $20 \mathrm{~km}$ W of Shiprock, San Juan Co, NM; N36 49' 4.7" W108 54' 44.2"; U18; 6 km N of Kanab, Kane Co, UT; $\mathrm{N} 37^{\circ} 6^{\prime} 16.0^{\prime \prime} \mathrm{W} 112^{\circ} 32^{\prime} 55.6^{\prime \prime}$. E. nummulare; U10; $17 \mathrm{~km} \mathrm{~N}$ of Dugway Proving Ground, Toole Co, UT; N40 20' 12.7" W112 36' 47.0". E. racemosum; U05; N Salt Lake City, Salt Lake Co, UT; N40 $47^{\prime} 28.5^{\prime \prime}$ W111 $51^{\prime}$ 42.7". E. smithii; U26; Little Flat Top, Emery Co, UT; N38 $32^{\prime} 15^{\prime}$ W110 $29^{\prime} 38.5^{\prime \prime}$; U27; N Texas Hill, Emery Co, UT; N38 30' 2.6" W110 24' $47.8^{\prime \prime}$. E. thompsoniae matthewsiae; U19; SW Zion Ntl Park, Washington Co, $\mathrm{UT} ; \mathrm{N} 37^{\circ} 11^{\prime} 47.4^{\prime \prime} \mathrm{W} 112^{\circ} 59^{\prime} 33.7^{\prime \prime}$. E. thompsoniae thompsoniae; U32; 4 $\mathrm{km} \mathrm{W}$ of Bloomington Hills, Washington Co, UT.; N37 $3^{\prime} 16.2^{\prime \prime}$ W113 $39^{\prime}$ 54.7"; U33; $4 \mathrm{~km}$ SE of Hurricane, Washington Co, UT; N37 $8^{\prime} 53.2^{\prime \prime}$ W113 15' 20.6"; U03; La Verkin, Washington Co, UT; N37 $13^{\prime} 8.6^{\prime \prime} \mathrm{W} 113^{\circ} 15^{\prime} 0^{\prime \prime}$; U04; Rockville, Washington Co, UT; N37 9' 42.4" W113 1' 56.6." 